\title{
Beware the lens of low-wage labour
}

\section{A review essay on "Low-wage work in the wealthy world", edited by Jerome Gautie and John Schmitt}

\author{
Guy Standing ${ }^{1}$
}

[Published in Contemporary Sociology: A Journal of Reviews, Vol.41, No.4, July 2012, pp.453-455; doi: 10.1177/0094306112449613b; http://csx.sagepub.com/content/41/4/453]

We lack a collective noun for a bevy of authors, but this book has no less than 26 named contributors, backed up by 11 project advisors and a team of 46 spread over six countries. It is a distinguished group of authorities in labour studies, united by social democratic values. Given all that, any sensible reviewer would approach the task with trepidation. One might risk offending one big elephant, but to risk the wrath of a herd would be career-threatening or worse.

So, let me start by saying that this is a good book on an important topic that should be on the reading list of all departments of labour studies. It is the result of what must have been an enormously expensive project funded by Russell Sage. There must have been numerous meetings, cross-Atlantic flights, expensive hotel bills, the occasional sumptuous dinner and much international re-bonding. Inevitably, one must gain and lose from such a process.

The potential gain is analytical cohesion, which the editors have responsibility for identifying, refining and conveying in their introduction and through their guidance to chapter authors. The potential loss is that the group obtains a coherence that is the lowest common denominator, with a platitudinous hypothesis as the guideline. Given these conflicting tendencies, it should not be surprising if one ends by giving a rating of five out of ten. The message seems to be that 'institutions matter'.

In short, one feels at times as if one is eating a pudding, with lots of fruit embedded in a lot of dough. The book is very long; it contains a wealth of facts, with a very selective set of references. But the taste is a little flat. One senses that the project was under-conceptualised and under-analytical.

One is entitled to judge a book as a stand-alone product, even though this is the concluding output of a project that drew on six country studies - Denmark, France, Germany, The Netherlands, the UK and the USA. A primary thesis is that the extent of low-wage labour varies by country, being dependent on national labour regulations, wage-bargaining systems and the "generosity of government benefits" (sic). The main methodology consisted ostensibly of "firm-level case studies" in "five industries", all of which are in services, so omitting the primary sector and manufacturing. Clearly, one can detect some biases already.

Rather than summarise the chapters or case studies, let me use this review article to highlight some concerns. The first is conceptual. The book is written by a group that could be called labour institutionalists, or labourists. They call labour 'work', thereby omitting all forms of work that are not covered by 'jobs'. This includes the work done by more people for more time than any labour, the

\footnotetext{
${ }^{1}$ Professor of Economic Security, University of Bath, England.
} 
work women do mainly, covered by the terms 'care work' and 'house work'. This continues the sexist labourist bias of the $20^{\text {th }}$ century. We must move out of that labourist trap.

The systemic omission of work that is not labour has numerous implications, but is particularly important for understanding labour and work in a tertiary society, which is what this book is about. For instance, the old notion of 'hours of work' is thoroughly misleading, since an increasing number of people in jobs and in the labour market must do a great deal of "work-for-labour" outside their formal workplace. So use of a measure such as 'hourly wages' is moot. One may hypothesise that if one were to measure wage income as an hourly rate taking into account all the necessary hours of work-for-labour that many workers have to undertake, one would obtain a much, much higher incidence of 'low-wage work'.

The book also seems to exclude those who are not "employees", which means it excludes a growing number of people, such as outworkers, self-employed contractors and diverse 'service providers'. While writing this review in an internet café, I asked six people whether or not they were 'employees'. None were, yet all should be called 'low-paid workers'.

In two of the chosen countries, Denmark and Germany, they also exclude apprentices, which happen to be important categories and to be among the lowest-paid, making it difficult to draw conclusions from tables showing small percentage differences in national shares of low-paid.

The conceptual and statistical problems become even more fundamental when one reflects on the growth in all the countries of so-called labour market flexibility. The trouble is that the book took a long time to come out, and as a result its data refer to the early years of this century. There are a few for 2007, but most are for long before that. There is nothing for the period of upheaval since the financial crash. The changes that have taken place in the past four years are enormous.

For instance, the incidence of 'poor' households containing someone in a job has shot up from what it was in 2001 (p.67). The probability of transition from 'low-pay' to 'better-pay' has plummeted since 2001 (p.50). ${ }^{2}$ The 'generosity' (sic) of means-tested assistance (p.168) has fallen and brought more problems of benefit exclusion that make average replacement rates almost meaningless.

Another conceptual point is sensitive. Is all low-wage labour 'bad'? A labourist may thunder that of course it is. In a tertiary society, one should be more circumspect. For instance, many who are employed for casual jobs are employed by their fellow citizens, who may be no wealthier than they are. Many students are only too glad to find low-paid labour in a bar to help pay for the rent. Many oldagers are delighted to do a few hours of low-paid labour in town, to give them activity and social interaction. Many people with disabilities are glad of a little extra.

\footnotetext{
${ }^{2}$ Social mobility is underplayed in the book. This relates to the point about occupation made later in this review. Incidentally, many of the book's tables are worthy of exam questions. Table 2.4 is a good example. It purports to show the probability of transition from low pay to better pay. The figures indicate that the probability of moving out of low pay is higher in the USA than in Denmark or France. But the text states that the US data refer to the probability of transition over two years, whereas in the other countries it is one year. That trainee could have been trained in those two years!
} 
The key point is that the potential worker should have the bargaining strength to be able to make a choice. In a service-oriented society, many jobs are intrinsically low-productivity activities. Some are dirty and dangerous. What is important is that safeguards should be mandatory while workers should be sufficiently secure to be able to refuse to do jobs that are 'bad'.

Then there are a few conventions used in the book that are irritants for this reviewer. For example, the authors refer to labour "de-regulation", when what has happened should be called "reregulation". There were more regulations introduced in the period covered than at any comparable period in history. Regulatory institutions were made more complex and directive, while the ethos shifted decisively from pro-collective to anti-collective and pro-individualistic. It conveys the wrong message to call what happened 'de-regulation', which implies the state became less interventionist.

Similarly, the term 'job security' is used when what is meant is 'employment security'. They are not the same; both were weakened in all the countries covered. Some employees, notably in the public sector, retained employment security, with mandatory notice periods, redundancy pay and so on. But many lost job security, being obliged to shift from job to job within their firm or organisation, often being required to undergo new 'training'. There has been a general erosion of labour security, covering many aspects of employment.

This leads to this reviewer's greatest regret about this book. It systematically neglects the occupational character of work, and the huge changes in occupational regulation that took place in all the countries in the period, most notably in the USA. ${ }^{3}$ It makes nonsense of notions of institutional regulation when one reflects on one stylised fact. In the early 1980s, about one in 20 American workers was subject to occupational licensing, that is, state regulation. Now, about one in every three is regulated in this way. How can a book on the importance of labour regulations and institutions neglect such a change?

The book thereby neglects one major cause of the growth of the precariat and of low-wage static labour. For what has happened is the regulatory dismantling of occupational communities, in which licensing boards have splintered professions and crafts into 'elites', earning high incomes and big benefits, with strong career prospects, alongside a precariat mass, with low wages, few if any benefits and little in the way of a career to anticipate. ${ }^{4}$ The outcome is worse than can be conveyed by dualisms of the sort used in the book, which makes much of 'low-pay vs high-pay', 'good jobs versus bad jobs' and 'high road versus low road business strategies'. The worst issue in the spread of low-wage labour is that it is part of the spread of chronic economic insecurity.

Having long worked on the issues covered by this book, I have become convinced that its framework is the problem. It is extremely difficult to escape a way of thinking, especially when one has built a reputation on work in that paradigm. But making 'jobs' the centre of thinking is to throw away the essence of work and leisure. We may have to accept that our jobs will be mostly instrumental, not central to our identities and career. Wealth in wealthy countries may come by other ways.

\footnotetext{
${ }^{3}$ I have analysed the regulatory and institutional changes elsewhere. See, for instance, G.Standing, Work after Globalization: Building Occupational Citizenship (Cheltenham and New York, Edward Elgar, 2009).

${ }^{4}$ G.Standing, The Precariat - The New Dangerous Class (London, Bloomsbury, 2011).
} 